\title{
ANALISIS SISTEM PENERAPAN BAGI HASIL TERHADAP PEROLEHAN LABA BERDASARKAN PRINSIP SYARI'AH
}

\author{
Ma'rifatun $^{1)}$, Akbar Yusuf ${ }^{2)}$, Herni Sunarya ${ }^{2)}$ \\ ${ }^{1)}$ Alumni Program Studi Akuntansi Universitas Muhammadiyah Kupang \\ ${ }^{2)}$ Dosen Tetap Program Studi Akuntansi Universitas Muhammadiyah Kupang
}

\begin{abstract}
ABSTRAK
Penelitian ini bertujuan untuk mengetahui apakah dalam sistem bagi hasil terhadap akuntansi syari'ah baik menggunakan sistem profit sharing maupun revenue sharing, telah adil terhadap stakeholder dan laba yang dihasilkan dari hasil usaha tersebut terdiri dari beberapa pihak didistribusikan berdasarkan prinsip syari'ah. Hasil penelitian menunjukkan bahwa pendistribusian laba pada perusahaan yang menerapkan akuntansi syariah telah mendistribusikan labanya tidak hanya kepada pemilik modal saja. Akan tetapi laba yang diperoleh juga didistribusikan kepada para stakeholder yang ada dalam perusahaan dengan membawa nilai-nilai Islam. Sedangkan keadilan dalam pendistribusian laba jika dilihat secara objektif belum bisa sepenuhnya dilakukan. Komposisi laba untuk pemilik modal masih lebih besar dibandingkan kepada stakeholder lainnya. Stakeholder adalah individu, sekelompok manusia, komunitas atau masyarakat baik secarakeseluruhan maupun secara parsial yang memiliki hubungan serta kepentingan terhadap perusahaan. Individu, kelompok, maupun komunitas dan masyarakat dapat dikatakan sebagai stakeholder jika memiliki karakteristik yaitu mempunyai kekuasaan, legitimasi, dan kepentingan terhadap perusahaan.
\end{abstract}

Kata kunci: Sistem Bagi Hasil Prinsip Syari'ah, Laba.

\section{PENDAHULUAN}

Pesatnya pertumbuhan Bank syariah di Indonesia belum dibarengi oleh pemahaman dan pengetahuan masyarakat tentang sistem operasional perbankan syariah. Meski bank syariah terus berkembang setiap tahunnya, namun dikalangan masyarakat Indonesia masih belum mengenal apa dan bagaimana bank syariah menjalankan kegiatan bisnisnya. Menurut masyarakat produk-produk yang ditawarkan oleh bank syariah, hanyalah produk-produk bank konvensional yang dipoles dengan penerapan akad-akad yang berkaitan dengan syariah. Sehingga hal ini pun menjadi pertanyaan bagi masyarakat mengenai karakteristik dasar yang melandasi sistem operasional perbankan syariah, yaitu sistem bagi hasil. Karena sistem bagi hasil dalam prakteknya masih menyerupai sistem bunga bagi bank konvensional. Begitu pula penyaluran dana bank syariah yang lebih besar bertumpu pada pembiayaan murabahah, yang mengambil keuntungan berdasarkan margin, dianggap oleh masyarakat hanyalah sekedar polesan dari cara pengambilan bunga pada bank konvensional.

Bagi hasil (profit sharing) merupakan distribusi beberapa bagian dari laba yang diperoleh dari hasil usaha kepada shahibul maal dan mudharib. Margin adalah pengambilan keuntungan dari hasil jual beli. Meski secara teoritis sistem bagi hasil dengan akad mudharabah dan musyarakah sangat baik, namun yang terjadi pembiayaan perbankan syariah dengan pola tersebut belum menjadi barometer bank syariah, sehingga perbandingannya cukup kecil jika dibandingkan dengan pembiayaan dengan pendapatan tetap. Hal tersebut lebih disebabkan pada tuntutan yang harus dipenuhi oleh bank syariah yang mengikuti struktur bank konvensional. 
Untuk bank konvensional dituntut untuk membagikan pendapatan atau return secara tetap bagi dana pihak ketiga di setiap bulannya.

Jika mekanisme ekonomi bank konvensional menggunakan instrument bunga, maka dalam mekanisme ekonomi islam adalah menggunakan instrument bagi hasil. Salah satu bentuk instrument kelembagaan yang menerapkan instrument bagi hasil adalah bisnis dalam lembaga keuangan syari'ah yaitu bank syari'ah. Dengan hadirnya Bank syari'ah diharapkan menjadi salah satu pilar penopang perekonomian negara dan sebagai penggerak sektor riil, yang akhirakhir ini menjadi solusi dan pilihan bagi banyak masyarakat baik islam ataupun non islam dalam bertransaksi keuangan secara syar'i islami dan Insya Allah aman dan selamat dunia akhirat.

Dalam sistem keuangan tanpa bunga (sistem keuangan syariah), yang berupaya dijalankan oleh para penganut prinsip-prinsip Islam, seseorang dapat memperoleh keuntungan dari uang mereka hanya dengan cara tunduk pada risiko yang termasuk dalam skema bagi hasil. Salah satunya adalah PT. Bank Muamalat Indonesia, Tbk yang berpedomaman pada prinsip syari'ah Islam. Nasabah yang terdapat dalam bank muamalat pun bukan hanya orang-orang muslim saja, tetapi masyarakat non muslim pun turut menggunakan jasa keuangan tersebut. Salah satu nilai dalam sistem syari' ah itu sendiri adalah keadilan dan pertanggung jawaban dalam pendistribusian bagi hasil. Berdasarkan uraian di atas, maka rumusan masalah yang diangkat adalah Bagaimanakah sistem bagi hasil terhadap perolehan laba berdasarkan prinsip syari'ah pada PT Bank Muamalat Indonesia, Tbk Cabang Kupang?

\section{TINJAUAN PUSTAKA}

\section{Pengertian Sistem dan Stakeholder Theory}

Murdick (1991:27) menjelaskan bahwa sistem adalah seperangkat elemen yang membentuk kumpulan atau prosedur/ bagan-bagan pengolahan yang mencari suatu tujuan bagian atau tujuan bersama dengan mengoperasikan data dan/atau barang pada waktu rujukan tertentu untuk menghasilkan informasi. Maksud dari suatu sistem adalah untuk mencapai suatu tujuan dan sasaran dalam ruang lingkup yang sempit.

Stakeholder adalah Individu, sekelompok manusia, komunitas atau masyarakat baik secara keseluruhan maupun secara parsial yang memiliki hubungan serta kepentingan terhadap perusahaan. Jika diperhatikan secara seksama dari definisi diatas maka telah terjadi perubahan mengenai siapa saja yang termasuk dalam pengertian stakeholder perusahaan. Sekarang ini perusahaan sudah tidak memandang bahwa stakeholder mereka hanya investor dan kreditor saja. Konsep yang mendasari mengenai siapa saja yang termasuk dalam stakeholder perusahaan sekarang ini telah berkembang mengikuti perubahan lingkungan bisnis dan kompleksnya aktivitas bisnis perusahaan. Stakeholder perusahaan sendiri dibagi kedalam dua bentuk besar, yaitu:

1) Primary stakeholders merupakan pihak-pihak yang mempunyai kepentingan secara ekonomi terhadap perusahaan dan menanggung risiko seperti misalnya investor, kreditor, karyawan, komunitas lokal namun disisi lain pemerintah juga termasuk kedalam golongan primary stakeholders walaupun tidak secara langsung mempunyai hubungan secara ekonomi namun hubungan diantara keduanya lebih bersifat nonkontraktual.

2) Secondary stakeholders adalah media dan kelompok kepentingan seperti lembaga social masyarakat, serikat buruh, dan sebagainya.

Perkembangan teori stakeholders membawa perubahan terhadap indikator kesusuksesan perusahaan. Ukuran keberhasilan perusahaan bukan lagi bagaimana besar laba 
yang diperoleh, melainkan bagaimana perusahaan bermanfaat dan memiliki nilai bagi para stakeholder. Akan tetapi jika dibawa ke prinsip syariah, teori stakeholder ini masih memiliki kekurangan. Teori stakeholder belum memasukkan Tuhan sebagai pemilik dari segala pemilik. Untuk itu munculah syariah enterprise theory yang memasukkan Tuhan dan nilai-nilai Islam ke dalam bagian dari perusahaan.

\section{Sistem Bagi Hasil (Profit Sharing)}

Menurut Muhammad (2012:26), bagi hasil (profit sharing) merupakan distribusi beberapa bagian dari laba pada para pegawai dari suatu perusahaan yang berbentuk suatu bonus uang tunai tahunan yang didasarkan pada laba yang diperoleh pada tahun-tahun sebelumnya, atau dapat berbentuk pembayaran mingguan atau bulanan. Adapun bentuk-bentuk pembagian laba yang tidak langsung mencakup alokasi saham-saham (penyertaan) perusahaan pada para pegawai, dibayar melalui laba perusahaan, dan memberikan para pegawai opsi untuk membeli saham-saham sampai pada jumlah tertentu dimasa yang akan datang pada tingkat harga sekarang, sehingga memungkinkan para pegawai memperoleh keuntungan baik dari pembagian deviden maupun setiap pertumbuhan dalam nilai saham yang dihasilkan dari peningkatan dalam kemampuan memperoleh laba.

Ada beberapa sistem bagi hasil yang terdapat dalam menentukan beberapa bagian yang diperoleh oleh masing-masing pihak yang terkait. Sistem bagi hasil yang pada dasarnya erat kaitannya dengan berapa marjin yang akan ditetapkan, ialah dengan Profit Sharing dan Revenue Sharing. Profit Sharing adalah perhitungan bagi hasil didasarkan kepada hasil net dari total pendapatan setelah dikurangi dengan biaya-biaya yang dikeluarkan untuk memperoleh pendapatan tersebut. Apabila suatu bank menggunakan sistem profit sharing, kemungkinan yang akan terjadi adalah bagi hasil yang akan diterima shahibul maal akan semakin kecil. Kondisi ini akan mempengaruhi keinginan masyarakat untuk menginvestasikan dananya pada bank Syariah yang berdampak menurunnya jumlah dana pihak ketiga secara keseluruhan. Sedangkan Revenue Sharing adalah perhitungan bagi hasil didasarkan kepada total seluruh pendapatan yang diterima sebelum dikurangi dengan biaya-biaya yang telah dikeluarkan untuk memperoleh pendapatan tersebut. Bank yang menggunakan revenue sharing kemungkinan yang akan terjadi adalah tingkat bagi hasil yang diterima oleh pemilik dana akan lebih besar dibandingkan tingkat suku bunga pasar yang berlaku, kondisi ini akan mempengaruhi pemilik dana untuk berinvestasi di bank syari'ah dan dana pihak ketiga akan meningkat.

Prinsip bagi hasil (profit sharing) sendiri merupakan karakteristik umum dan landasan dasar operasional bank syari'ah. Secara keseluruhan prinsip dalam perbankan syari'ah yang paling banyak dipakai adalah:

1) Akad utama Al-Musyarakah dan Al-Mudharabah.

a. Al-Musyarakah berarti akad kerja sama antara dua pihak atau lebih untuk suatu tertentu dimana masing-masing pihak memberikan kontribusi dana dengan kesepakatan bahwa keuntungan dari resiko akan ditanggung bersama sesuai dengan kesepakatan.

b. Al-Mudharabah berarti akad kerjasama usaha antara dua pihak dimana pihak pertama (shahibul mal) memberikan dana $100 \%$ kepada pihak kedua (mudharib) yang memiliki keahlian.

2) Pembiayaan oleh beberapa bank Islam (plantation financing) mempergunakan $\mathrm{Al}$ Muzaro'ah dan Al-Musakoh.

a. Al-Muzaro'ah berarti kerjasama pengelola pertanian antara pemilik lahan dan penggarap, dimana pemilik lahan memberikan lahan pertanian kepada si penggarap untuk ditanami dan dipelihara dengan imbalan bagian tertentu (prosentase) dari hasil panen. 
b. Al-Musakoh mempunyai bentuk yang lebih sederhana dari muzaro'ah, dimana si penggarap hanya bertanggungjawab atas penyiraman dan pemeliharaan sabagian imbalan, si penggarap berhak atas nisbah tersebut dari hasil panen.

Ada dua faktor yang mempengaruhi bagi hasil yaitu faktor langsung seperti investment rate; jumlah dana yang tersedia; nisbah bagi hasil, dan faktor tidak langsung seperti penentuan butir-butir pendapatan dan biaya bank serta nasabah melakukan share dalam pendapatan dan biaya; Kebijakan Accounting.

\section{Pengertian Laba}

Menurut Baridwan (1992:31) laba adalah kenaikan modal yang berasal dari transaksi sampingan atau transaksi yang jarang terjadi dari suatu badan usaha dan dari semua transaksi atau kejadian lain yang mempengaruhi badan usaha selama satu periode kecuali yang timbul dari pendapatan atau investasi oleh pemilik. Menurut Sitepu (2005:29) laba terbagi kedalam empat jenis dalam kaitannya dengan laba rugi, yaitu:

1) Laba kotor, adalah selisih dari hasil penjualan dengan harga pokok penjualan;

2) laba operasional merupakan hasil dari aktivitasa-aktivitas yang termasuk rencana perusahaan kecuali ada perubahanperubahan besar dalam perekonomiannya, dapat diharapkan akan dicapai setiap tahun;

3) laba sebelum dikurangi pajak merupakan laba operasi ditambah hasil dan biaya diluar operasi biasa. Bagi pihak-pihak tertentu terutama dalam hal pajak, angka ini adalah yang terpenting karena jumlah ini menyatkan laba yang pada akhirnya dicapai perusahaan; dan

4) laba bersih adalah laba setelah dikurangi berbagai pajak. Laba dipindahkan kedalam perkiraan laba ditahan. Dari perkiraan laba ditahan ini akan diambil sejumlah tertentu untuk dibagikan sebagai dividen kepada para pemegang saham. Menurut Skousen (1989:119) laba bersih merupakan perbedaan antara jumlah pendapatan yang diperoleh suatu satuan usahan selama periode tertentu dan jumlah biaya yang dapat diaplikasikan kepada pendapat.

Popularitas istilah laba sendiri disebabkan oleh fungsi laba yang sangat vital bagi perusahaan. Laba berfungsi sebagai standar penilaian kinerja (performance) perusahaan yang selanjutnya menjadi dasar pertimbangan kreditor, investor, pemerintah, dan masyarakat umum. Menurut Sitepu (2005:38), pendistribusian net income perusahaan dapat dilihat dari konsepkonsep antara lain Net Income to Stockholders, Net Income to Investor, dan Net Income to Residual Shareholders.

\section{Prinsip Syari'ah}

Pada dasarnya syari'ah adalah seluruh ajaran islam yang berupa norma-norma ilahiyah, baik yang mengatur tingkah laku batin (sistem kepercayaan/doctrinal) maupun konkrit (legal/ formal) yang individual dan kolektif. Al-syari'ah identik dengan din, yang berarti meliputi seluruh cabang pengetahuan keagamaan islam, seperti kalam, tasawuf, tafsir, hadis, fiqih, usul fiqih, dan seterusnya. Adapun beberapa landasan yang menjadi dasar hukum syari'ah, yaitu:

a. Menurut ketentuan syari'at, sistem bunga bank (interest) adalah sama dengan riba yang haram hukumnya. Contohnya seperti yang tertulis dalam QS.Ar-Rum:39 yang berbunyi “dan sesuatu Riba (tambahan) yang kamu berikan agar Dia bertambah pada harta manusia, Maka Riba itu tidak menambah pada sisi Allah. dan apa yang kamu berikan berupa zakat yang kamu maksudkan untuk mencapai keridhaan Allah, Maka (yang berbuat demikian) Itulah orang-orang yang melipat gandakan (pahalanya)." 
b. Menurut Hadits, Abdullah bin Umar r.a. menjelaskan bahwa ada seseorang laki-laki mengatakan kepada Nabi Shalallahu'alaihi wasallam bahwa dia telah menipu dalam jualbeli, maka beliau bersabda:

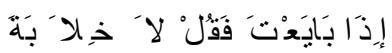

“Apabila kamu menjual, maka katakanlah: 'Tidak ada penipuan (HR. Bukhari).”

3) Menurut Ijma' Ulama menyatakan bahwa dalam mukaddimah ini dinukil sebuah kaedah masyhur, yang diungkapkan oleh seorang tokoh ulama pergerakan bernama: Sayyid Muhammad Rasyid Ridha. Ungkapan itu berbunyi:

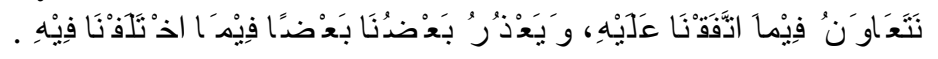

"Kita bantu-membantu dalam masalah yang kita sepakati dan bersikap toleran dalam masalah yang kita perselisihkan.”,

4) Menurut Pakar, Dr, Yusuf Al-Qaradhawi membuat sebuah kaidah atau ungkapan yang berbunyi, "Kita bantu-membantu (tolong-menolong) mengenai apa yang kita sepakati dan bersikap toleran dalam masalah yang kita perselisihkan seperti Al-Allamah Sayyid Rasyid Ridha rahimahullah, pemimpin madrasah Salafiyyah Al-Haditsah, pemimpin majalah AlManar al-Islamiyyah yang terkenal itu, pengarang tafsir, fatwa-fatwa, risalah-risalah, dan kitab-kitab yang mempunyai pengaruh besar terhadap dunia Islam."

Allah berfirman: Prinsip dasar syari' ah dikelompokkan menjadi dua hal yaitu Prinsip pertanggungjawaban dan prinsip keadilan.

a. Prinsip pertanggung jawaban (Accountability) merupakan konsep yang tidak asing lagi dikalangan masyarakat muslim. Pertanggungjawaban selalu berkaitan dengan konsep amanah. Bagi kaum muslim, persoalan amanah merupakan hasil transaksi manusia dengan sang Khaliq mulai dari alam kandungan.

b. Prinsip Keadilan yang jika ditafsir lebih lanjut, ayat 282 surat Al-Baqarah mengandung prinsip keadilan dalam melakukan transaksi. Prinsip keadilan ini tidak saja merupakan nilai yang sangat penting dalam etika kehidupan sistem dan bisnis, tetapi juga merupakan nilai yang secara linheren yang melekat dalam fitrah manusia. Hal ini berarti bahwa manusia itu pada dasarnya memiliki kapasitas dan sistem untuk berbuat adil dalam setiap aspek kehidupannya.

\section{Kerangka Berpikir dan Hipotesis}

Sistem bagi hasil berdasarkan prinsip syari' ah adalah kumpulan dari beberapa bagian dalam pendistribusian bagi hasil yang meliputi profit sharing dan revenew sharing dan mempunyai hubungan antara nasabah, perusahaan dan Sang Khaliq dalam perolehan laba dari hasil usaha Adapun kerangka berpikir dalam penelitian ini adalah sebagai berikut:

$$
\begin{aligned}
& \text { Penerapan Sistem Bagi Hasil } \\
& \text { Berdasarkan Prinsip Syari'ah: } \\
& \text { - } \quad \text { Revenue Sharing } \\
& \text { - } \quad \text { Profit Sharing }
\end{aligned}
$$

\section{Perolehan Laba}

Dari kerangka berpikir di atas dapat ditarik kesimpulan bahwa, "Jika penerapan sistem bagi hasil dilakukan berdasarkan prinsip syari'ah akan memperoleh laba yang saling menguntungkan berdasarkan prinsip syari'ah." 


\section{METODE PENELITIAN}

\section{Lokasi dan Rancangan Penelitian}

Lokasi penelitian ini adalah PT. Bank Muamalat Indonesia Tbk Cabang Kupang. Jenis metode penelitian yang digunakan adalah penelitian kualitatif yang dilakukan dengan tujuan utama untuk memberikan gambaran atau deskripsi tentang suatu keadaan secara objektif. Jenis data yang digunakan adalah data kualitatif. Sumber data yang digunakan adalah data primer yang diperoleh melalui wawancara terhadap responden dan data sekunder yang diperoleh dari buku-buku, jurnal-jurnal. Teknik pengumpulan data yang digunakan adalah dokumentasi dan kuesioner.

\section{Teknik Analisis Data}

Teknik analisis data yang digunakan adalah analisis kualitatif deskriptif yang bertujuan untuk menggambarkan dan mengungkapkan suatu masalah, keadaan, peristiwa sebagaimana adanya atau mengungkapkan fakta secara mendalam mengenai analisis sistem bagi hasil terhadap perolehan laba berdasarkan prinsip syari'ah pada PT Bank Muamalat Indonesia, Tbk Cabang Kupang. Data-data perusahaan yang mendukung penelitian dikumpulkan kemudian data-data tersebut dilakukan analisa dengan cara mendikripsikan atau menggambarkan keadaan obyek penelitian yang sesungguhnya. Analisa data ini penting artinya karena dari analisa ini data yang diperoleh dapat memberi arti dan makna yang berguna dalam memecahkan masalah dalam penelitian ini.

\section{HASIL DAN PEMBAHASAN}

Untuk melakukan penelitian terhadap analisis penerapan bagi hasil terhadap akuntansi syariah, peneliti mencari data laporan keuangan dan data keuangan lainnya dari objek penelitian, serta melakukan wawancara terhadap salah satu karyawan PT. Bank Muamalat Indonesia Tbk dan juga memberikan kuesioner kepada beberapa nasabah Bank Muamalat Indonesia, Tbk. Cara-cara tersebut dianggap cukup praktis bagi peneliti dalam melakukan penelitian. Oleh karena itu, berdasarkan penelitian yang dilakukan mengenai Analisis Penerapan Sistem Bagi Hasil Terhadap Akuntansi Syari' ah, maka diperoleh informasi sebagai berikut:

\section{Hasil Kuesioner \\ Profit Sharing}

Dari hasil jawaban responden perihal profit sharing, besaran nisbah yang digunakan adalah ditentukan berdasarkan kesepakatan masing-masing pihak yang berkontrak, utamanya untuk kontrak mudharabah muqayyadah, namun untuk kontrak mudharabah mutlaqah, untuk bank syariah dapat ditentukan oleh pihak bank. Sebab, pembagian bagi hasilnya sudah tersistem melalui komputerisasi. Angka nisbah berfariasi, misalnya 50:50, 60:40, 70:30, 80:20, bahkan 99:1, untuk bank dan nasabah atau sebaliknya. Di bank muamalat, tawar-menawar nisbah antara pemilik modal dan bank syariah hanya terjadi bagi deposan/investor dengan jumlah besar, karena memiliki daya tawar yang tinggi. Kondisi ini disebut dengan spesial nisbah.

Sedangkan untuk nasabah deposan kecil, biasanya tawar menawar tidak terjadi. Bank muamalat hanya mencantumkan nisbah yang ditawarkan, setelah itu deposan boleh setuju boleh tidak. Bila setuju maka nasabah akan melanjutkan menabung. Bila tidak setuju, nasabah dipersilahkan mencari bank syariah lain yang menawarkan nisbah yang lebih menarik. Jadi berdasarkan jawaban responden mengenai profit sharing adalah nasabah setuju dan bagi hasil yang mereka terima telah sesuai dengan apa yang telah disepakati di awal perjanjian.

\section{Revenue Sharing}

Dari hasil jawaban responden pendistribusian bagi hasil dengan cara revenue sharing menyetujui akan pembagian bagi hasilnya. Nasbah masih terus bertahan melanjutkan tabungan 
atau mendepositokan dananya di Bank Muamalat sampai sekarang. Nasabah merasakannya secara langsung baik itu berupa financial (bagi hasil) atau pun berupa non financial (pelayanan service). Bagi hasil yang diterima lebih besar karena sebelum dikurangi untuk memperoleh pendapatan tersebut.

\section{Prinsip Syari’ah dalam Pendistribusian Bagi Hasil \\ Prinsip Pertanggungjawaban}

Menurut Muhammad, Prinsip pertanggung jawaban (Accountability) selalu berkaitan dengan konsep amanah. Bagi kaum muslim, persoalan amanah merupakan hasil transaksi manusia dengan sang Khaliq mulai dari alam kandungan. Manusia diciptakan oleh Allah sebagai khalifah di muka bumi. Manusia dibebani amanah oleh Allah untuk menjalankan fungsi-fungsi kekhalifahannya. Inti kekhalifahan adalah menjalankan atau menunaikan amanah.

Dalam pendistribusian laba pada PT. Bank Muamalat Indonesia, Tbk telak menjalankannya sesuai dengan amanat dan ketentuan yang berlaku secara syari'ah. Dimana bagi hasil nasabah diberikan sesuai dengan nisbah bagi hasil yang telah disepakati bersama pada saat awal perjanjian/akad. Apabila terdapat perubahan nisah bagi hasil maka akan di putuskan bersama antar shahibul mall dengan mudharib.

\section{Prinsip Keadilan}

Prinsip keadilan ini tidak saja merupakan nilai yang sangat penting dalam etika kehidupan sistem dan bisnis, tetapi juga merupakan nilai yang secara Iinheren yang melekat dalam fitrah manusia. Hal ini berarti bahwa manusia itu pada dasarnya memiliki kapasitas dan 35ystem untuk berbuat adil dalam setiap aspek kehidupannya.

Dalam konteks akuntansi, kata adil dalam ayat 282 surat Al-Baqarah dijelaskan apabila bermu'amalah tidak secara tunai untuk waktu yang ditentukan, hendaklah menuliskannya (mencatat) dengan benar tanpa mengurangi sedikitpun daripadanya. Jika orang yang berhutang itu orang yang kurang akalnya atau lemah keadaanya, maka hendaklah walinya yang membayarkannya dihadapan dua orang saksi. Semua mu'amalah yang tidak secara tunai harus dilakukan pencatatan agar tidak ada kelalaian di kemudian hari. Jika kamu lakukan (yang demikian), maka sesungguhnya hal itu adalah suatu kefasikan pada dirimu. Dan bertakwalah kepada Allah, Allah memberikan pengajaran kepadamu, dan Allah Maha mengetahui segala sesuatu.

\section{Konsep Laba dalam Akuntansi Syariah}

Banyak hal yang membedakan antara akuntansi konvensional dengan akuntansi syariah. Salah satunya adalah mengenai konsep pendistribusian laba yang diperoleh dalam suatu perusahaan. Di dalam perusahaan yang berbasis syariah, laba bukanlah menjadi tujuan utama melainkan Allah SWT. Sehingga segala aktivitas yang terjadi adalah untuk menambah kedekatan kita kepada Allah SWT. Begitu juga dengan bagi hasil, nilai-nilai Islam harus senantiasa kita terapkan guna mendekatkan diri kita kepada Allah SWT. Salah satu nilai yang diajarkan adalah nilai keadilan.

Sistem bagi hasil pada PT. Bank Muamlat Indonesia Tbk. Dapat dilihat dari laporan keuangan yang disajikan. PT. Bank Muamalat Indonesia Tbk. belum menggunakan konsep value added income statement, selain karena belum diwajibakan perbankan syariah untuk menerapkan, data-data yang tercantum dalam laporan keuangan dianggap telah mencakup datadata yang ada dalam value added income statement. Untuk lebih jelasnya, sistem bagi hasil PT. Bank Muamalat Indonesia Tbk dapat dilihat dalam laporan laba rugi sebagai berikut: 
Tabel 1

P.T. BANK MUAMALAT INDONESIA Tbk.

LABA RUGI

PERIODE 31 DESEMBER

TAHUN 2012, 2011 DAN 2010

\begin{tabular}{|c|c|c|c|}
\hline KETERANGAN & TAHUN 2012 & TAHUN 2011 & TAHUN 2010 \\
\hline $\begin{array}{l}\text { PENDAPATAN PENGELOLAAN DANA } \\
\text { OLEH BANK SEBAGAI MUDHARIB }\end{array}$ & 2.980 .144 & 2.319 .733 & 1.608 .141 \\
\hline Pendapatan dari penjualan & 1.439 .610 & 1.082 .688 & 690.573 \\
\hline Pendapatan dari bagi hasil & 1.247 .995 & 990.649 & 782.431 \\
\hline Pendapatan dari ijarah-bersih & 18.150 & 45.983 & 50.176 \\
\hline Pendapatan usaha utama lainnya & 274.388 & 200.413 & 84.962 \\
\hline \multicolumn{4}{|l|}{$\begin{array}{l}\text { Jumlah Pendapatan Pengelolaan Dana } \\
\text { oleh Bank sebagai Mudharib }\end{array}$} \\
\hline $\begin{array}{l}\text { HAK PIHAK KETIGA ATAS BAGI HASIL } \\
\text { DANA SYIRKAH TEMPORER }\end{array}$ & $(1.457 .940)$ & $(1.156 .734)$ & $(764.601)$ \\
\hline HAK BAGI HASIL MILIK BANK & 1.522 .203 & 1.162 .999 & 843.540 \\
\hline $\begin{array}{l}\text { PENDAPATAN OPERASIONAL } \\
\text { LAINNYABERSIH }\end{array}$ & 402.692 & 354.797 & 279.698 \\
\hline BEBAN PENYISIHAN PENGHAPUSAN & $(151.541)$ & $(127.524)$ & $(96.306)$ \\
\hline Aset Produktif & $(88.799)$ & $(125.826)$ & $(90.054)$ \\
\hline Aset Non Produktif & $(62.741)$ & $(1.697)$ & $(6.252)$ \\
\hline \multicolumn{4}{|l|}{ Jumlah Beban Penyisihan Penghapusan } \\
\hline BEBAN OPERASIONAL LAINNYA & $(1.248 .827)$ & $(1.006 .653)$ & $(788.653)$ \\
\hline Beban kepegawaian & $(546.875)$ & $(410.355)$ & $(253.303)$ \\
\hline Beban umum dan administrasi & $(573.879)$ & $(498.888)$ & $(482.611)$ \\
\hline $\begin{array}{l}\text { Pemulihan (beban) estimasi kerugian } \\
\text { komitmen dan kontijensi }\end{array}$ & $(558)$ & $(3.601)$ & $(365)$ \\
\hline Beban bonus giro wadiah & $(34.637)$ & $(21.845)$ & $(11.223)$ \\
\hline Beban Lain-lain & $(92.878)$ & $(71.963)$ & $(41.881)$ \\
\hline \multicolumn{4}{|l|}{ Jumlah Beban Operasional } \\
\hline LABA OPERASIONAL & 524.527 & 383.619 & 238.279 \\
\hline LABA (RUGI) NON OPERASIONAL & $(2.686)$ & $(11.949)$ & $(7.202)$ \\
\hline Pendapatan non operasional & 19.160 & 20.911 & 10.772 \\
\hline Beban non operasional & $(21.845)$ & $(32.860)$ & $(17.973)$ \\
\hline LABA SEBELUM PAJAK & 521.841 & 371.670 & 231.077 \\
\hline MANFAAT (BEBAN) PAJAK & $(132.427)$ & $(98.049)$ & $(60.138)$ \\
\hline LABA BERSIH & 389.414 & 273.622 & 170.939 \\
\hline LABA BERSIH PER SAHAM & 53 & 185 & 116 \\
\hline
\end{tabular}

Sumber : PT. Bank Muamalat, 2012

Distribusi Laba untuk Pemilik Dana

\section{Pemegang Saham}

Berdasarkan Rapat Umum Pemegang Saham Tahunan yang diselenggarakan pada tanggal 28 Juni 2011, para pemegang saham telah memutuskan untuk melakukan penyisihan sebagian laba bersih tahun 2010 sebesar Rp 37.896.347.000 ke dalam pos laba ditahan yang 
akan diakumulasikan dengan dividen tahun buku 2011. Sedangkan pembagian laba kepada para pemegang saham untuk tahun laba 2011, berdasarkan Rapat Umum Pemegang Saham tanggal 26 Mei 2012 yang diaktakan dengan Akta Notaris Arry Supratno, S.H., No. 21, tanggal 2 Agustus 2012 para pemegang saham setuju untuk meningkatkan modal ditempatkan dan disetor penuh dari Rp 782.667.194.000,- atau 1.400.004.552 saham menjadi Rp 821.843.363.000,- atau 1.478.356.890 saham. Penambahan modal disetor sebesar Rp 39.176.169.000,- berasal dari pembagian dividen saham. Dalam hal perbandingan laba yang akan diperoleh antara pemegang saham dengan nasabah tabungan, keduanya memiliki perhitungan yang berbeda. Misalnya saja, A memiliki saham sejumlah 25.000.000 lembar saham. Dengan menggunakan laba per saham dasar sebesar Rp. 115,63 per saham, maka si A akan mendapatkan laba sebesar Rp 115,63 x 25.000.000 = Rp 2.890.750.000,-. Sedangkan jika nilai saham tersebut Rp 25.000.000.000 (jumlah saham dikalikan harga saham) di depositokan, maka si A akan memperoleh bagi hasil sebesar:

$$
\begin{gathered}
\text { Bagi Hasil Nasabah }=\frac{F p 25.000 .000 .000}{1.000} \times 8.09 \times 100 \\
=R p 109.215 .000
\end{gathered}
$$

Bagi Hasil Nasabah dalam 1 tahun $=$ Rp 109.215.000,- x $12=$ Rp 1.310.580.000,- Jika di lihat perbandingan di atas, maka jumlah yang diperoleh pemegang saham masih lebih besar ketimbang nasabah yang mendepositokan uangnya. Padahal dana yang mereka punya sama, di simpan dalam waktu yang sama. Bahkan para pemegang saham memiliki hak suara dibanding para deposan.

\section{Nasabah}

Penetapan bagi hasil di Bank Muamalat dilakukan dengan terlebih dahulu mengitung HI-1000 (baca: Ha-i-seribu), yakni angka yang menunjukkan hasil investasi yang diperoleh dari penyaluran setiap Rp. 1.000 dana nasabah. Sebagai contoh: HI-1000 bulan Mei 2009 adalah 9,99. Hal tersebut berarti bahwa dari setiap Rp. 1.000,- dana nasabah yang dikelola Bank Muamalat akan menghasilkan Rp. 9,99 (HI-1000 sebelum bagi hasil). Apabila nisbah bagi hasil antara nasabah dan bank untuk deposito 1 bulan adalah 50:50, maka dari Rp. 9,99 tersebut, untuk porsi nasabah dikalikan dahulu dengan 50\% sehingga untuk setiap Rp. 1.000,- dana yang dimiliki, nasabah akan memperoleh bagi hasil sebesar Rp. 4,99 (berarti HI-1000 nasabah = 4,99 rupiah). Secara umum hal tersebut dirumuskan sebagai berikut:

$B H N=\frac{\text { Rata }- \text { rata Dana Nasabah }}{1.000} \times H I-1000 \times \frac{\text { Nisbah Nasabah }}{100}$

Keterangan:

BHN: Bagi Hasil Nasabah

Sebagai contoh, seorang nasabah (Pak Slamet) menyimpan deposito Mudharabah di Bank Muamalat pada bulan Mei senilai Rp. 10.000.000,- dengan jangka waktu 1 bulan. Diketahui nisbah deposito 1 bulan 50:50. HI-1000 untuk bulan Mei 10,93. Maka untuk mengetahui nilai bagi hasil yang akan didapatkan Pak Slamet adalah

$$
\begin{aligned}
& B H N=\frac{R p 10.000 .000}{1.000} \times 10,93 \times \frac{50}{100} \\
= & R p 54.650
\end{aligned}
$$

Nisbah yang akan diperoleh nasabah akan berbeda-berbeda tiap layanan karena PT. Bank Muamalat Indonesia Tbk. memberikan nisbah kepada nasabahnya sebagai berikut: 
Tabel 2

Nisbah Bagi Hasil Tabungan

\begin{tabular}{|l|c|}
\hline \multicolumn{1}{|c|}{ Tabungan } & Nisbah \\
\hline Tabungan Muamalat: & \\
- Share Gold & $22 \%$ \\
- Share Regular & $7,5 \%$ \\
\hline Tabungan Muamalat Sahabat & $2 \%$ \\
\hline Tabungan Muamalat Umroh & $30 \%$ \\
\hline Tabungan Arafah Plus & $10 \%$ \\
\hline Tabungan Wisata & $30 \%$ \\
\hline Tabungan Prima & \\
- SRR < Rp 25.000.000,- & $10 \%$ \\
- SRR Rp. 25.000.000,- s/d Rp. 49.999.999,- & $20 \%$ \\
- SRR Rp. 50.000.000,- s/d Rp. 99.999.999,- & $40 \%$ \\
- SRR Rp 100.000.000,- s/d Rp. 250.000.000,- & $48 \%$ \\
- SRR > Rp 250.000.000,- & $52 \%$ \\
\hline
\end{tabular}

Sumber: PT. Bank Muamalat Indonesia Tbk, 2013

Tabel 4.4

Nisbah Deposito PT. Bank Muamalat Indonesia Tbk.

Deposito Nisbah Nasabah

\begin{tabular}{|l|c|}
\hline \multicolumn{1}{|c|}{ Jangka Waktu Deposito } & Nisbah Bagi Hasil \\
\hline Deposito Rupiah1 Bulan & $50 \%$ \\
\hline Deposito Rupiah 3 Bulan & $51 \%$ \\
\hline Deposito Rupiah 6 Bulan & $53 \%$ \\
\hline Deposito Rupiah 12 Bulan & $54 \%$ \\
\hline Deposito USD 1 Bulan & $17 \%$ \\
\hline Deposito USD 3 Bulan & $19 \%$ \\
\hline Deposito USD 6 Bulan & $21 \%$ \\
\hline Deposito USD 12 Bulan & $23 \%$ \\
\hline
\end{tabular}

Sumber: PT. Bank Muamalat Indonesia Tbk, 2013

Perbedaan besarnya nisbah tiap layanan disebabkan karena perbedaan manfaat dan fasilitas yang diperoleh serta syarat-syarat yang diberikan. Misalnya saja pada tabungan muamalat Shar-E Gold dan Shar-E Reguler. Shar-E Gold memiliki saldo minimum sebesar Rp 250.000,- yang hanya dapat ditarik keseluruhan ketika ingin menutup tabungan. Sedangkan Shar-E Reguler memiliki saldo minimum Rp 10.000,-,. Untuk tahun 2011, PT. Bank Muamalat Indonesia Tbk. memberikan hak pihak ketiga atas bagi hasil dana syirkah temporer sebesar Rp 1.156.734.283.000,- dan meningkat tahun 2012 sebesar Rp 1.457.940.000.000,-. Naiknya besaran bagi hasil tersebut dapat diartikan bahwa nasabah Bank Muamalat dari tahun 2011 meningkat. Peningkatan ini disebabkan karena meningkatnya tingkat kepercayaan nasabah akan pengelolaan dana mereka oleh Bank Muamalat. Nasabah lebih merasa aman menyimpan dana mereka pada bank syariah di tengah keadaan ekonomi yang tidak menentu.

\section{Distribusi Laba untuk Karyawan}

Pada tahun 2011, Bank Muamalat dengan bantuan konsultan profesional mulai mengembangkan sistem jenjang karir karyawan, sebagai bagian terpadu dari pola pengembangan human capital di Bank Muamalat bersama dengan strategi remunerasi dan 
penerapan PMS. Rasio pemberian gaji berbeda antar karyawan. Hal ini dinilai berdasarkan jenjang karir, tingkat pendidikan, dan pengalaman. Biaya gaji yang dikeluarkan PT. Bank Muamalat Indonesia pada tahun 2012 adalah sebesar Rp. 410.355.072.000 dan tahun 2010 sebesar Rp 253.302.852.000. Human capital divition (HCD) senantiasa berupaya memaksimalkan penggunaan anggaran yang dialokasikan untuk pelatihan dan pendidikan karyawan Bank Muamalat sehingga mencapai hasil secara efektif. Total biaya untuk pelatihan karyawan pada tahun 2011 tercatat sebesar Rp 17.481 miliar, atau 5,12\% dari total biaya tenaga kerja pada tahun tersebut, dibandingkan dengan Rp 7.232 miliar yang dikeluarkan pada tahun 2010. Dengan adanya penambahan budget biaya training dari tahun 2010 sampai 2011, earning per karyawan mengalami peningkatan dari Rp 94,6 juta di tahun 2010 menjadi Rp 109,48 juta di tahun 2011. Dari sisi earning juga mengalami peningkatan dari Rp 273 miliar tahun 2010 menjadi Rp 375 miliar di tahun 2011 (naik 37\%). Jumlah karyawan Bank Muamalat sebelumnya tercatat sebesar 2.946 orang pada akhir tahun 2010 meningkat menjadi 3.696 orang pada tahun 2011 yang terdiri dari karyawan dengan status tetap, kontrak maupun outsourcing. Ini mencerminkan tingkat pertumbuhan (net growth) yang signifikan sebesar 25\% pada tahun 2011. Peningkatan beban kepegawaian lebih besar dibandingkan peningkatan jumlah karyawan. Hal ini dapat diartikan bahwa perhatian perusahaan baik masalah gaji, pengembangan karir, dan sebagainya meningkat. Selama tiga tahun terakhir, tingkat atrisi karyawan adalah sebagai berikut 4,66\% pada tahun 2009, 4,39\% tahun 2010 dan 5,41\% di tahun 2011. Angka-angka tersebut relatif rendah jika dibandingkan dengan rata-rata industri perbankan syariah maupun konvensional. Hal ini membuktikan sistem pengembangan karyawan lebih terencana sesuai dengan kebutuhan bisnis dan organisasi, sehingga meminimalisir perpindahan dan mobilisasi dalam lingkungan perusahaan, serta dapat menjadi salah satu indikasi membaiknya tingkat keterlibatan karyawan (employee engagement) di Bank Muamalat.

\section{Keadilan Dalam Pendistribusian Laba}

Menurut Wiroso $(2010,27)$, prinsip keadilan esensinya menempatkan sesuatu hanya pada tempatnya dan memberikan sesuatu hanya pada yang berhak serta memperlakukan sesuatu sesuai posisinya. Implementasi keadilan dalam kegiatan usaha berupa aturan prinsip muamalah yang melarang adanya unsur riba, kezaliman, Maysir (unsur judi), Gharar (unsur ketidak jelasan) dan haram.

Bank Muamalat sebagai bank murni syariah tidak menganut sistem bunga yang menjadi unsur riba dalam perbankan. Bank Muamalat menggunakan sistem bagi hasil sebagai bentuk pendistribusian keuntungan kepada para nasabah. Besarnya bagi hasil berdasarkan pada jumlah keuntungan yang diperoleh. Bila usaha merugi, kerugian akan ditanggung bersama oleh kedua belah pihak. Hal ini akan dinilai lebih adil dibanding sistem bunga yang memberikan tambahan pada pokok uang yang di simpan atau dipinjamkan tanpa memperhitungkan untung rugi yang mengelola dana. Pendistribusian laba dalam Bank Muamalat juga menghindari unsur kezaliman yaitu unsur yang merugikan diri sendiri, orang lain, maupun lingkungan. Para karyawan diberikan upah dan bonus yang senantiasa meningkat seiring dengan peningkat laba perusahaan.

\section{Hasil Jawaban Responden}

Dari 20 nasabah yang terdiri dari bermacam-macam profesi, berbeda keyakinan dan berlatar belakang pendidikan yang berbeda menyatakan bahwa dalam pembagian bagi hasil kepada nasabah telah diberikan sesuai dengan porsi nisbah yang telah ditentukan pada saat akad perjanjian disetujui. Dari hasil jawaban responden tersebut bisa disimpulkan bahwa keadilan 
dan pertanggungjawabann telah dijalankan oleh bank muamalat. Dimana dalam pembagian bagi hasil dan laba telah sesuai dengan besarnya porsi nisbah yang disepakati diawal.

Di bidang lingkungan sekitar, Bank Muamalat menggunakan zakat perusahaan, karyawan, dan nasabah untuk kegiatan-kegiatan sosial. Laba juga didistribusikan untuk dana cadangan umum yang berguna untuk menjaga kelangsung perusahaan. Dalam hal Gharar, Bank Muamalat bersikap terbuka kepada para stakeholdernya. Sebelum menandatangi akad, akan dijelaskan mengenai hak dan kewajiban bank dan para nasabah. Hi-1000 sebagai dasar penentuan bagi hasil tiap bulannya di umumkan agar nasabah dapat menghitung sendiri berapa besar keuntungan yang akan diperoleh. Bank Muamalat menerbitkan Annual Report tiap tahunnya yang berisikan tentang laporan kinerja Bank Muamalat baik keuangan maupun non keuangan. Sehingga pemerintah dapat mengetahui besaran pajak yang dikeluarkan, para pemegang saham dapat mengetahui besar keuntungan yang diperoleh, serta distribusi zakat dapat diketahui.

\section{KESIMPULAN DAN SARAN}

Berdasarkan hasil penelitian yang didukung data dan informasi yang telah dikemukakan sebelumnya, penulis menarik kesimpulan bahwa: Pertama, sistem bagi hasil pada PT. Bank Muamalat Indonesia, Tbk terdiri dari profit sharing dan revenue sharing. Kedua, sistem bagi hasil terhadap perolehan laba pada PT Bank Muamalat Indonesia, Tbk Cabang Kupang telah didistribusikan kepada shahibul maal dan mudharib dengan adil berdasarkan prinsip syari'ah. Ketiga, laba yang dihasilkan oleh sebuah perusahaan terdiri dari banyak pihak yang terlibat di dalamnya, diantaranya adalah pemilik dana, karyawan, dan lingkungan. Dengan adanya perspektif adil, maka laba tidak saja dinikmati oleh sekelompok kecil pemilik perusahaan, tetapi juga dapat dinikmati oleh seluruh stakeholder dan keempat, Implementasi keadilan yang melarang adanya unsur riba, kezaliman, Maysir, Gharar, dan haram telah diimplementasikan oleh Bank Muamalat dalam aktivitas usahanya.

Berdasarkan kesimpulan di atas, maka peneliti menyarankan kepada perusahaan untuk lebih patuh menjalankan prinsip syari'ah agar bagi hasil terhadap perolehan laba lebih adil dalam mendistribusikan dan dapat menarik investor untuk menanamkan dana di bank muamalat indonesia. Dan juga agar lebih memperhatikan fasilitas-fasilitas yang dibutuhkan oleh nasabah. Seperti service excellent lebih di tingkatkan lagi, mensosialisasikan E-Banking ( Phone banking, Mobile banking, Internet banking) kepada nasabah agar bisa memanfaatkan fasilitas yang telah disediakan, Sehingga keadilan dalam pendistribusian laba dapat diterapkan. Selanjutnya saran untuk peneliti-peneliti yang tertarik untuk mengambil penelitian yang sama agar dapat membandingkan antara penerapan pendistribusian laba berdasarkan bank syari'ah denga bank konvensional sehingga dapat dilihat perbedaan yang mendasar dan melihat konsep mana yang lebih adil.

\section{DAFTAR PUSTAKA}

Al- Qur'an dan Terjemahannya

Djojodihardjo.2003.”Sistem Pengendalian Intern”. Salemba Empat. Jakarta.

Eferin, Dkk. 2004. "Metode Penelitian untuk Akuntansi”. Banyumedia. Malang.

Islahuzzaman. 2012. "Istilah-istilah Akuntansi dan Auditing”. Bumi Aksara. Jakarta.

Ismail.2011."Akuntansi Bank”. Kencana Media Group. Jakarta.

Laksamana, Yusak. 2009. “ Panduan Praktis Accounting Officer Bank Syari'ah”. PT. Gramedia. Jakarta. 
Muhammad,M.Ag. 2002. "Pengantar Akuntansi Syari'ah”. Salemba Empat. Jakarta

Muhammad. 2012. "Teknik Perhitungan Bagi Hasil dan Pricing di Bank Syari'ah”.UII Press. Yogyakarta.

Muhammad, 2010. “ Undang-undang Perbankan Syari'ah”. Bumi Aksara. Jakarta Murdick.2007. "Sistem Informasi Akuntansi”, Graha Ilmu. Yogyakarta

Mutaher, Osmad. 2012.”Akuntansi Perbankan Syari'ah”. Graha Ilmu.

Yogyakarta.

Umar, Husein.2003.”Metode Riset Akuntansi Terapan”. Ghalia Indonesia. Jakarta

Sitepu,Waktu. 2005."Analisis Perbandingan Pendistribusi Laba Bersih Akuntansi

Konvensional dan Akuntansi Syari'ah”. Bandung.

Sumar' in. 2012."Konsep Kelembagaan Bank Syari'ah". Graha Ilmu. Yogyakarta.

http://www.kajianpustaka.com/2013/03/05/11:23/teori-prinsip-bagi-hasil-syari'ah.html

http://www.inkopsyahbmt.co.id

http://www.carapedia.com/2013/01/14/15:01/pengertiandefinisianalisis info2056.html

http://www.sarjanaku.com/2013/03/06/16:45/pengertiansistemmenurutparaahli.html

http://www.scribd.com/doc/2013/03/06/17:00/ALK-pengertian-dll

http://sro.web.id/pengertian-sistem.html/2013/03/06/17:18/bagi hasil.html

http://www.muamalatbank.com/2013/04/16/18:46/produk.html

http://www.carapedia.com/2013/09/01/13:19/pengertian operasional.html

http://www.scribd.com/doc/2013/08/25/13:30/stackeholder.html 